\title{
A Calibrated Trade Model of Agglomeration
}

\author{
By \\ Paul Friesen \\ Department of Economics and Finance, University of Guelph \\ Stephen Kosempel \\ Department of Economics and Finance, University of Guelph \\ kosempel@uoguelph.ca
}

\section{Department of Economics and Finance University of Guelph Discussion Paper 2009-15}

This is the pre-peer reviewed version of the following article: Friesen, P. \& Kosempel, S. (2010). A Calibrated Trade Model of Agglomeration. Review of International Economics, 18 (4), 714-729. The final publication of this article is available at:

http://onlinelibrary.wiley.com/

DOI: http://dx.doi.org/10.1111/j.1467-9396.2010.00898.x 
A Calibrated Trade Model of Agglomeration

by Paul Friesen and Stephen Kosempel

\begin{abstract}
This paper explores just how good the idea of international agglomeration of industry can be at explaining observed economic differences between countries. An international trade model with industrial agglomeration is outlined and calibrated to real data from the World's 10 largest countries by population, in order to assess how well it can explain the gap between rich and poor countries, observed trade volumes, price differences, and other types of data. The model is revealing in showing that, given the existing location of labor, an asymmetric exogenous distribution of firms is enough to generate income disparity and other stylized facts.
\end{abstract}

Corresponding author: Stephen Kosempel, Department of Economics and Finance, University of Guelph, Guelph, Ontario, Canada N1G 2W1. Phone: (519) 824-4120 x56339; Fax: (519) 763-8497; E-mail: kosempel@uoguelph.ca. 


\section{Introduction}

The primary objective of this paper is to explore just how good the idea of international agglomeration of industry can be at explaining observed economic differences between countries. In international agglomeration models, development and underdevelopment are manifestations of the clustering of economic activity. Certain activities such as manufacturing have a tendency to cluster together, because they create an environment for each other which is beneficial to all. Some countries have many such clustered activities, creating a high demand for labor, high wages, and high prices for the things being produced. These countries are therefore rich. Poor countries are the ones that got left out during the formation of the clusters. In them, the demand for labor is low, and this produces low wages and low prices for those goods that are produced.

The analysis is performed using a model of international trade, which is not very unlike the Heckscher-Ohlin framework, or that of Markusen and Venables (2007). There are, however, a few crucial differences. Under the above, the key determinant of trade patterns is considered to be resources, including human and/or physical capital, which are thought of as being 'nailed down' in particular country; whereas in this paper it is the production firms that are immobile. A version of this model containing 10 countries will be calibrated to real data from the World's largest countries by population, in order to assess how well it can explain the gap between rich and poor countries, observed trade volumes, price differences, and other types of data. The model is revealing in showing that, given the existing location of labor, an asymmetric exogenous distribution of firms is enough to generate income disparity and other stylized facts.

The explanation provided by the model for many of the economic differences that exist among nations requires that restrictions be placed on the mobility of labor and firms in the 
model, because international movements of either would tend to equalize wages and other prices between countries. The restriction on the movement of labor between countries is an obvious feature of the real world. The restriction on the movement of firms is assumed to be present due to agglomeration (or clustering) of industry.

In that this paper studies the effects that the clustering of manufacturing and other production activities have on international trade, prices and welfare, it resembles the work in the New Economic Geography (NEG) literature, ${ }^{1}$ but this paper focuses on the effects of agglomeration of industry, rather than the causes. The models in the NEG literature are interesting partly because of the way in which they derive at least some of the forces which lead to the agglomeration of industry from the rational, profit and utility maximizing decisions of agents. However, if we are more interested in examining the effects of agglomeration than its causes, a type of model which is, at least conceptually, much simpler can be used. We do not need to model the mechanisms of agglomeration. We can simply assume the clustering property. Although a firm in a rich country has an incentive to move to a poor country to obtain cheaper labor, we assume that the other costs of leaving its cluster are high enough to more than offset this advantage. There are many potential reasons for the reluctance of firms to move to low wage rate countries including endowments, technology, institutional quality, and geographic location. ${ }^{2}$ We simply study worldwide economic outcomes, taking as given the locations of labor and firms at a point in time. This simplification makes it practical to add more complexity in other areas.

In that this paper presents a trade model with industrial agglomeration and studies the properties of the general equilibrium using numerical simulation, it resembles the works of Krugman and Venables (1995), Puga and Venables (1999), and Fujita et al. (1999). However, 
this paper differs from these other papers in three important ways. First, the focus of these other papers is on identifying the forces that lead to agglomeration of industry and the spread of industry over time; whereas the focus in this paper is on explaining detailed characteristics of global economic activity at a point in time, including trade flows and international price differences. Second, these earlier models were not calibrated to specific economies; whereas the current model is calibrated in an attempt to explain several stylized facts in the World's 10 most populated countries. Third, in some respects the production structure of our model is richer than in these other models. For example, the Krugman and Venables' model has only two production sectors and two regions; whereas our model has 5 production sectors and 10 countries, and therefore we are able to say more about how agglomeration affects international economic outcomes. Although Puga and Vennables (1999) and Fujita et al. (1999) also present models with many industrial sectors and many countries, all goods produced in their models are tradable; whereas our model also has non-tradable sectors.

The inclusion of non-tradeable sectors allows us to rectify a significant problem with NEG models. These models normally produce the counter-factual result that generalized price indexes are higher in poor countries than in rich ones, because more goods are made in rich countries, and incur shipping costs when sold in poor countries. In this paper, we also consider other costs of importation and costs associated with final distribution. We assume that importation and final distribution requires the input of a non-traded service supplied by the destination country. And since non-traded goods and services are cheaper in poor countries due to low factor prices, our model is able to produce the real-world observation that poor countries normally have lower price levels. 
In that this paper quantifies the effects of agglomeration of industry on relative incomes, it also resembles the work of Redding and Venables (2004). Their paper identifies both the causes of agglomeration and its effects on relative incomes using a partial equilibrium trade and geography model with one production sector - manufacturing. In comparison, in this paper we study the global general equilibrium in a model that is calibrated to a large number of countries and sectors. These additional sectors enable us to identify some effects of agglomeration that were not studied in the Redding and Venables paper; such as the allocation of resources between sectors, the composition of output, trade volumes, and relative prices within and across countries.

\section{The Model}

The model has $J$ countries. Each model country has 5 industries: a farming industry, a manufacturing industry; a construction industry; a tradeable services industry; and a nontradeable services industry. These industries produce a large number of goods, as will become clear later. However, there are just 7 general types of goods, which are either used as inputs by industries or consumed by the population. These 7 general types of goods are: (1) a food composite, (2) a manufacturing composite, (3) a tradeable services composite, (4) a construction industry output, (5) a non-tradeable services industry output, (6) labor, and (7) land. While we do not model capital separately, spending on capital is considered to be included in spending on manufacturing and construction, and firms choose their level of spending to maximize profits.

\section{The Industries}

All countries have the same production function within each industry, but production functions 
are assumed to differ across industries. The production functions are all constant returns to scale. ${ }^{3}$ All industries are modelled as if they were perfectly competitive, and profits are zero. Under these conditions firms will be willing to supply any amount of output demanded at the market price. The objective of any firm will be to produce a given amount of output at minimum cost, taking prices and their location as given, and subject to the condition that input demands are nonnegative. The conditional factor demand functions are easily found using standard methods.

The Farming Industry. Each country is modelled as producing a single agricultural output good under perfect competition, which is different from the agricultural output good of any other country. However, all of these different goods have the same production function. In a CobbDouglas function, all inputs are required to produce output. But farming, as practised in poor countries, will often use amounts of manufacturing, construction, and services which are essentially zero. Instead of using these things, farmers just use their own labor. For this reason, an agricultural production function is adopted that reflects this property:

$$
\begin{aligned}
& Y_{F}^{j}=\left(M_{F}^{j}+k_{M} L_{F}^{j}\right)^{\beta_{F}}\left(C_{F}^{j}+k_{C} L_{F}^{j}\right)^{\gamma_{F}}\left(X_{F}^{j}+k_{X} L_{F}^{j}\right)^{\delta_{F}}\left(S_{F}^{j}+k_{S} L_{F}^{j}\right)^{\delta_{F}} L_{F}^{j \zeta_{F}} T_{F}^{j \eta_{F}} \\
& \beta_{F}+\gamma_{F}+\delta_{F}+\varepsilon_{F}+\zeta_{F}+\eta_{F}=1 .
\end{aligned}
$$

Here $Y_{F}^{j} \quad$ is the number of units of agricultural output for countr $M_{F}^{j} \quad$ is manufacturing composite input, $C_{F}^{j} \quad$ is constructi $X_{F}^{j} \quad$ is tradeable services com $S_{F}^{j}$ ite, $\quad$ is non-tradeable services, $L_{F}^{j} \quad$ is labor, $c T_{F}^{j} \quad$ is the arable land input. Other symbols are positive constant parameters. This has constant returns to scale in all inputs together. $L_{F}^{j} \quad \varepsilon T_{F}^{j} \quad$ are necessary inputs, without which output is zero. Other inputs are optional. Production may take place 
without them, because labor can be used as a substitute.

The Manufacturing Industry. This industry is modelled following Fujita et al. (1999). It consists of a large number of activities, each of which produces a unique product. These activities are identical in the sense that they all have the same production function,

$$
\begin{aligned}
& Y_{M n}=F_{M n}{ }^{\alpha_{M}} M_{M n}{ }^{\beta_{M}} C_{M n}{ }^{\gamma_{M}} X_{M n}{ }^{\delta_{M}} S_{M n}{ }^{z_{M}} L_{M n}{ }^{5 . M}, \\
& \alpha_{M}+\beta_{M}+\gamma_{M}+\delta_{M}+\varepsilon_{M}+\zeta_{M}=1 .
\end{aligned}
$$

Here $Y_{M n}$ is the number of units of output for manufacturing activity $n, F_{M n}$ is food composite input to manufacturing activity $n, M_{M n}$ is manufacturing composite input, $C_{M n}$ is construction input, $X_{M n}$ is tradeable services composite, $S_{M n}$ is non-tradeable services, and $L_{M n}$ is labor. There are $N$ manufacturing activities located throughout the world, but only $N^{j}$ of these activities are located in country $j$. As in Fujita et al. (1999), manufacturing composite is an input to each manufacturing activity. This means that each activity uses as input, output from all of the other activities, plus a small amount of its own output. Formation of the composite is described later.

All manufacturing activities within a country face the same set of input prices. The zero profits assumption then implies that all of the various output goods have the same price per unit, again, only within each country. Prices, in general, differ between countries. As will be seen later, the assumptions regarding the formation of the various composite goods imply that, if goods have the same price, they will be used in equal quantities. Thus, all manufacturing activities within country $j$ produce equal units of output and, because of cost minimization, use equal amounts of each input. This means that we can write, instead of equation (2),

$$
Y_{M}^{j}=F_{M}^{j^{\alpha_{M}}} M_{M}^{j \beta_{M}} C_{M}^{j \gamma_{M}} X_{M}^{j^{\delta_{M}}} S_{M}^{j^{s_{M}}} L_{M}^{j \zeta_{M}}
$$


Here, $Y_{M}^{j} \quad$ is the total number of units produced by all of the manufacturing activities in country $j$, i.e. $Y_{M}^{j} \quad$ is just $N^{j}$ times the value of $Y_{M n}$ which is common to all of the manufacturing activities of country $j$. Similarly, $F_{M}^{j} \quad$ is $N^{j}$ times the country's common value of $F_{M n}$, and so on.

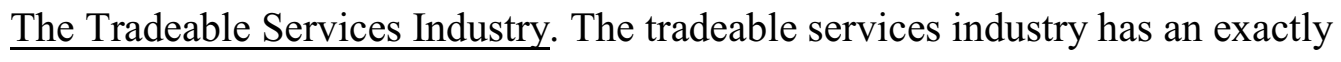
analogous structure to the manufacturing industry. The notation below uses an $I$ subscript to index a particular activity in this industry, an $I^{j}$ to denote the number of tradeable service activities located in country $j$, and an $I$ to denote the total number of these activities in the world. The equations analogous to (2) and (3) are

$$
\begin{aligned}
& Y_{X i}=F_{X i}^{\alpha_{x}} M_{X i}^{\beta_{x}} C_{X i}^{{ }^{\gamma} x} X_{X i}^{{ }^{\sigma_{x}}} S_{X i}^{{ }^{2 x}} L_{X i}{ }^{\xi x}, \\
& Y_{X}^{j}=F_{X}^{j^{\alpha_{x}}} M_{X}^{j^{\beta_{x}}} C_{X}^{j^{\gamma_{x}}} X_{X}^{j^{\delta_{x}}} S_{X}^{j^{\delta_{x}}} L_{X}^{j \varsigma_{x}}, \\
& \alpha_{X}+\beta_{X}+\gamma_{X}+\delta_{X}+\varepsilon_{X}+\varsigma_{X}=1 .
\end{aligned}
$$

Variable definitions are analogous. For example, $Y_{X}^{j} \quad$ is the total number of units produced by all of the tradeable service activities in country $j$, i.e. $Y_{X}^{j} \quad$ is just $I^{j}$ times the value $Y_{X i} \quad$ that is common to all tradeable service activities in country $j$.

The Construction and Non-Tradeable Services Industries. These industries are considered to produce a single output good for each, which is identical in all countries and not traded between countries. The production functions are

$$
\begin{aligned}
& Y_{C}^{j}=F_{C}^{j \alpha_{c}} M_{C}^{j \beta_{C}} X_{C}^{j \delta_{C}} S_{C}^{j \varepsilon_{C}} L_{C}^{j \zeta c}, \alpha_{C}+\beta_{C}+\delta_{C}+\varepsilon_{C}+\zeta_{C}=1, \\
& Y_{S}^{j}=F_{S}^{j \alpha_{s}} M_{S}^{j \beta_{S}} C_{S}^{j \gamma_{s}} X_{S}^{j \delta_{s}} L_{S}^{j \zeta s}, \alpha_{S}+\beta_{S}+\gamma_{S}+\delta_{S}+\zeta_{S}=1 .
\end{aligned}
$$


Variable definitions are analogous. These industries do not use their own output as input.

\section{Composite Goods}

Each country produces three types of composite goods: manufacturing composite, tradeable services composite and food composite. Composites are used for consumption and as inputs, and are not internationally traded. The markets for composites are assumed to be perfectly competitive, production functions are all constant returns to scale, and profits are zero.

Consider the manufacturing composite first. It is assumed that all of the different manufactured goods are combined (or aggregated), using a constant elasticity of substitution (CES) function, to form the manufacturing composite good. Let $Y_{M n}^{j} \quad$ denote the amount of manufacturing good $n$ to be used to make the manufacturing composite in country $j$. The amount of composite for country $j$ is given by

$$
M^{j}=\left[\sum_{n-1}^{N} Y_{M n}^{j}{ }^{\rho_{M}}\right]^{1 / \rho_{M}} \quad 0<\rho_{M}<1 \quad, .
$$

The problem to be solved by a representative firm in country $j$ is to make the amount of composite ordered at the least cost, given the prices in country $j$ of all of the different

manufactured goods, $P_{M_{1}}^{j} \rightarrow P_{M_{N}}^{j} \quad$. The conditional demand functions for this are well known.

As mentioned above, due to the structure of the model all manufactured goods produced in a particular country will sell for the same price in country $j$. Equation (8) implies that the manufactured goods are imperfect substitutes for each other. If the price of one country's goods rises, all countries will use less of its goods to make a given amount of composite, but they will always use some. The degree of substitutability is controlled by $\rho_{M}$. 
Tradeable services composite is made in an exactly analogous way,

$$
X^{j}=\left[\sum_{i=1}^{I} Y_{X i}^{j} \rho_{X}\right]^{1 / \rho_{X}} \quad 0<\rho_{X}<1 \quad, \quad .
$$

Here $Y_{X i}^{j} \quad$ denotes the amount of the type $i$ tradeable service used to make the tradeable services composite in country $j$. The problem to be solved by a representative firm in country $j$ is to make the amount of composite ordered at the least cost, given the prices in country $j$ of all of the different tradeable services, $P_{X_{1}}^{j} \rightarrow P_{X_{I}}^{j}$

Finally, the amount of food composite produced in country $j$ is given by a CES function

$$
F^{j}=\left[\sum_{z=1}^{J} Y_{F z}^{j} \rho_{F}\right]^{1 / \rho_{F}} \quad 0<\rho_{F}<1
$$

Here $Y_{F z}^{j} \quad$ denotes the quantity of country $z$ 's food used to make composite in country $j$. Once again, the problem to be solved by a representative firm in each country is how to assemble a given amount of composite at the lowest possible cost, given the prices of the different

foods, $P_{F_{1}}^{j} \rightarrow P_{F_{J}}^{j}$

\section{International Trade}

Each country engages in international trade; importing and exporting manufactured goods, tradeable services, and food. Other goods are not traded. Each of the three types of internationally traded goods has three types of costs to get the product of an industry to its final user. First, if the good is shipped between countries, tradable service composite must be supplied by the source country for shipping. The amount of the tradeable service composite used to ship one unit of food, manufacturing, or tradeable services is $t_{F}, t_{M}$, and $t_{X}$; respectively. Second, if the good is 
shipped between countries, it also requires the use of non-tradable services supplied by the destination country to import it. This represents customs duty and brokerage, plus less definable costs such as regulatory compliance, non-tariff trade barriers, and the costs of operating in a foreign country. The number of units of non-tradable services required for a unit of imported good are $r_{F}, r_{M}$, and $r_{X}$. Third, for all of the above traded goods there is a distribution cost for the composite after it is formed, representing wholesale and retail trade. This also requires nontradeable services output from the destination country. The amount required for a unit of the composites are $d_{F}, d_{M}$, and $d_{X}$. Note that these distribution costs relate to composite goods, which incorporate both foreign and domestic production.

Let $X_{\text {tansp }}^{j} \quad$ denote the total amount of tradeable services composite used to ship country

$j$ 's exports, and $S_{\text {truzp }}^{j} \quad$ be the total amount of non-tradable services required for importation and final distribution of goods in $j$. Separating the costs of exporting, importing, and distribution in this way plays an important role in the model, and one which separates this model from others that have attempted to explain international relative price differences. Price data reveals that the average prices of manufactured goods and tradeable services are lower in poor countries. This is a surprising fact, given that most of these goods are produced in wealthy countries, and therefore incur shipping costs. However, in this model, the average prices of manufactured goods and tradeable services also reflects the cost of non-tradeable services that are required for importation and final distribution, and these costs will be lower in poor countries where labor is cheap.

Since the model is static, each country must have balanced trade overall. However, a country may have surpluses with some of its partners, balanced by deficits with others. 


\section{The Population}

The population in country $j$ consists of $L^{j}$ identical agents. The population receives rent for its land, $T^{j}$, and wages for its labor. Let $r^{j}$ denote the rental rate of land in country $j$, and $w^{j}$ the wage rate per worker. It spends these on the same commodities as used for inputs to the industries. Let $F_{P}^{j} \quad M_{P}^{j} C_{P}^{j} \quad X_{P}^{j} \quad S_{P}^{j} \quad$, and denote per capita consumption of food composite, manufacturing composite, construction, tradeable services composite, and non-tradeable services

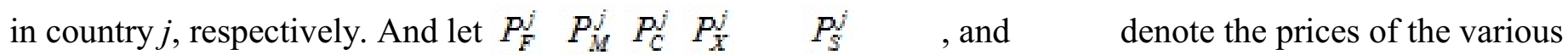
inputs in country $j$. The budget constraint for a representative member is given by

$$
P_{F}^{j} F_{P}^{j}+P_{M}^{j} M_{P}^{j}+P_{C}^{j} C_{P}^{j}+P_{X}^{j} X_{P}^{j}+P_{S}^{j} S_{P}^{j} \leq r^{j}\left(T^{j} / L^{j}\right)+w^{j} .
$$

The utility function for a representative member of the population is given by

$$
\begin{aligned}
& V^{j}=\left(F_{P}^{j}-F_{0}\right)^{\alpha_{D}}\left(M_{P}^{j}-M_{0}\right)^{\beta_{D}}\left(C_{P}^{j}-C_{0}\right)^{\gamma_{D}}\left(X_{P}^{j}-X_{0}\right)^{\delta_{D}}\left(S_{P}^{j}-S_{0}\right)^{\delta_{D}} \\
& \alpha_{P}+\beta_{P}+\gamma_{P}+\delta_{P}+\varepsilon_{P}=1 .
\end{aligned}
$$

The symbols $F_{0}, M_{0}, C_{0}, X_{0}$ and $S_{0}$ are parameters common to all countries. These parameters are sometimes thought of as subsistence levels of consumption below which utility is not defined. Equation (12) is a Stone-Geary utility function, and was chosen to give the model the ability to match the observed variations in spending patterns as countries become richer. In particular, with this type of utility function the model can reproduce Engel's law, which states that poor people devote a higher fraction of income to food and other necessities than rich people. ${ }^{4}$

The objective of a representative agent is to maximize (12) subject to (11) and to the condition that no input be negative. 


\section{The General Equilibrium}

Within each country, labor is assumed to move freely between sectors so wages are equalized.

Other prices are also equalized within countries. Prices are not, in general, equalized between countries. For land, labor and the non-traded output goods (construction and non-tradeable services), there is no international equalization mechanism. For the traded goods, the existence of trade costs means that equalization is incomplete.

Let $A \in(F, M, X, C, S)$ denote the set of industry types. The competitive general equilibrium consists of an allocation for the industries of each country,

$$
\begin{aligned}
& \left.\left\{Y_{A}^{j}, F_{A}^{j}, M_{A}^{j}, X_{A}^{j}, C_{A}^{j}, S_{A}^{j}, L_{A}^{j}, T_{A}^{j}\right\}\right|_{j=1} ^{J}, \forall A \\
& \text { country, }\left.\left\{F^{j}, M^{j}, X^{j},\left.Y_{F z}^{j}\right|_{z=1} ^{J},\left.Y_{M n}^{j}\right|_{n=1} ^{N}, Y_{X i}^{j} \mid \begin{array}{l}
I \\
i=1
\end{array}\right\}\right|_{j=1} ^{J} \\
& \text { country, }\left.\left\{F_{P}^{j}, M_{P}^{j}, X_{P}^{j}, C_{P}^{j}, S_{P}^{j}, L^{j}, T^{j}\right\}\right|_{j=1} ^{J} \\
& \left.\left\{P_{F}^{j}, P_{M}^{j} P_{X}^{j}, P_{C}^{j}, P_{S}^{j}, r^{j}, w^{j},\left.P_{F z}^{j}\right|_{z=1} ^{J},\left.P_{M n}^{j}\right|_{n=1} ^{N},\left.P_{X i}^{j}\right|_{i=1} ^{I}\right\}\right|_{j=1} ^{J}
\end{aligned}
$$

; an allocation for compos

; an allocation for th

(i) the allocations received by all firms solve their cost minimization problems, given prices;

(ii) the allocations received by each population solve their utility maximization problems, given prices; and

(iii) all markets clear. Market clearing requires that the total amount demanded for each good equals the amount produced, the demand for land by the farming industry equals the supply of arable land in the country, and the total labor demand within a country equals the population of that country: $Y_{F}^{j}=\sum_{z=1}^{J} Y_{F j}^{z}, \forall j ; \quad Y_{M n}=\sum_{j=1}^{J} Y_{M n}^{j}, \forall n, \quad Y_{X i}=\sum_{j=1}^{J} Y_{X i}^{j}, \forall i$ 


$$
\begin{aligned}
& Y_{C}^{j}=C_{F}^{j}+C_{M}^{j}+C_{X}^{j}+C_{S}^{j}+C_{P}^{j}, \forall j ; \quad Y_{S}^{j}=S_{F}^{j}+S_{M}^{j}+S_{X}^{j}+S_{C}^{j}+S_{P}^{j}+S_{\text {transp }}^{j}, \forall j ; \\
& F^{j}=F_{M}^{j}+F_{X}^{j}+F_{C}^{j}+F_{S}^{j}+F_{P}^{j}, \forall j ; \quad M^{j}=M_{F}^{j}+M_{M}^{j}+M_{X}^{j}+M_{C}^{j}+M_{S}^{j}+M_{P}^{j}, \forall j ; \\
& X^{j}=X_{F}^{j}+X_{M}^{j}+X_{X}^{j}+X_{C}^{j}+X_{S}^{j}+X_{P}^{j}+X_{\text {transp }}^{j}, \forall j ; T^{j}=T_{F}^{j}, \forall j ; \\
& L^{j}=L_{F}^{j}+L_{M}^{j}+L_{X}^{j}+L_{C}^{j}+L_{S}^{j}, \forall j
\end{aligned}
$$

\section{Calibration and Comparative Statics}

This section describes how parameter values are set. There are 74 parameters in the model. The values for 23 of these parameters will be set directly using real world data. The remaining 51 parameters will be placed in a set of 'free parameters', and these will be set so that the model economies match, as closely as possible, certain features of their real world counterparts. A program was created in $\mathrm{C}++$ to search the space defined by the model's 51 free parameters for the parameter set where the data generated from the model's general equilibrium matches the real world data most closely. ${ }^{5}$

The model has $J=10$ countries, which are intended to represent the largest 10 countries of the world by population. In order of decreasing GDP per capita, they are: Japan, USA, Brazil, Russia, China, Indonesia, India, Pakistan, Bangladesh, and Nigeria.

\section{Technology Parameters Common to All Countries}

The manufacturing, construction, non-tradeable services, and tradeable services industries are all modelled using Cobb-Douglas production functions with the same factor shares in each country. 
These factor shares were estimated using data from the national accounts of India and the USA. These two countries were chosen for an analysis of industry inputs and consumer spending, because they both provide detailed absorption matrices and other necessary information in a convenient form, and because they have very different per capita GDP figures, thus providing two well separated points. The expenditure shares for these two countries are displayed in Table 1. The assumption that the manufacturing, construction, tradeable services, and non-tradeable services industries all have constant factor shares across countries seems reasonably consistent with this data. The shares in the Cobb-Douglas production functions [equations (2)-(7)] are set using the average figures for the two countries.

"INSERT Table 1 here"

The data in Table 1 reveals that India and the USA have different factor shares in agricultural production. In general, the agricultural production function [equation (1)] will also lead the model to predict different expenditures shares in this industry across countries. The factor shares in agriculture from Table 1 are included in the data which the program attempts to match. The most important parameters in determining these shares will be the 10 parameters in agricultural production function. Table 2 displays the model's predicted values for the expenditure shares on the various inputs for agricultural production for each country. The model's estimated share values provide a good match with the data.

"INSERT Table 2 here"

There are 12 remaining technology parameters that are common to all countries: the 3 parameters that determine the elasticities of substitution in equations (8)-(10), $\rho_{M}, \rho_{X}$, and $\rho_{F}$; and 9 trade cost parameters, $t_{F}, t_{M}, t_{X}, r_{F}, r_{M}, r_{X}, d_{F}, d_{M}$, and $d_{X}$. The parameter $\rho_{M}$ affects the degree to 
which different manufactured goods can substitute for each other. A value close to 1 would mean that these goods are quite substitutable, and countries will tend to use large amounts of those that are cheap and small amounts of expensive ones when they assemble manufacturing composite. This would tend to make poor countries, whose goods are cheap, better off than they would be if the goods were poorer substitutes. The parameters $\rho_{X}$ and $\rho_{F}$ are analogous.

The trade costs parameters are set primarily so that the model can produce reasonable levels for the costs of international shipping, other import costs, and final distribution costs. However, altering one of the trade cost parameters will have other effects on the model too. For example, increasing one of the shipping costs parameters will reduce trade volume and increase price differences for the affected goods between producing and consuming countries. Table 3 shows that the values set for the model's trade costs parameters generate estimates of shipping and distribution costs that are of the magnitude observed in the data. Cost of importation, other than shipping, are often difficult to observe and therefore measure. However, there is lots of indirect evidence to support our finding that these costs are quantitatively significant. For example, McCallum (1995) and Helliwell (1996) found that merchandise trade flows among Canadian provinces were 20 times as dense as those between Canadian provinces and US states, and this is true even after controlling for the effects of size and distance. Similar results exist for other countries (Helliwell, 1997; Head and Meyer, 2000; and Fidrmuc and Fidrmuc, 2003).

\section{"INSERT Table 3 here"}

\section{Preference Parameters (these are common to all countries)}

The expenditure share data provided in Table 1 reveals that the shares of income spent on the various goods differ between India and the USA. The program can adjust the utility function 
parameters $\left(\alpha_{P}, \beta_{P}, \gamma_{P}, \delta_{P}, \varepsilon_{P}, F_{0}, M_{0}, C_{0}, X_{0}, S_{0}\right)$ in its attempts to match the expenditure shares for India and the USA in Table 1, as well as all its other data. Table 2 presents the model's predicted values for the expenditure shares of consumption by country. The model reproduces the trends in the data reasonably well, including the observation that poor people spend a higher fraction of their income on food.

\section{Country Specific Parameters}

All remaining parameter values are country specific. The countries modelled are assumed to be identical except for 4 things. These are the population, $L^{j}$; the arable land area, $T^{j}$; the number of manufacturing activities, $N^{j}$; and the number of tradeable service activities, $I^{j}$. These 4 types of parameters (40 in total) must be set for each country. Values for population and arable land area are taken from World Development Indicators database. The other 2 types of parameter are included in the set of free parameters, and are available for the program to adjust. In general changing any parameter has many different effects, the intuition for which can be complex. We will discuss only some of the more obvious effects.

First, increasing the number of activities in manufacturing in country $j$ increases aggregate demand for its manufactures. But the extra activities demand more labor. To keep the demand for labor in line with the fixed population, wages rise. This is where the assumption of agglomeration is crucial, because a manufacturing firm in a rich country would face cheaper labor costs if it moved to a poor one. Changes in $N^{j}$ have many other effects too. Among the most obvious are, for example, the increased value of manufacturing exports and the increased manufacturing workforce that an increase of this type would cause in country $j$. 
Increasing the number of tradeable services activities is exactly analogous to an increase in manufacturing activities. Therefore, like $N^{j}$, the parameter $I^{j}$ will determine the relative size of industry within a country and affect relative incomes across countries.

\section{The Main Results}

In this section the analysis is focussed on explaining international differences in per capita income, prices, and the allocation of resources between sectors. Table 4 presents more actual data compared to the artificial data from the model simulation. The data is from various sources. Price data is from the International Comparisons Programme, Phase V (United Nations, 1994). Other data is from World Development Indicators database. Data is for 1998 if available, otherwise a nearby year was selected. Price data is for 1985 , the only year detailed data is available.

The countries in Table 4 are arranged in descending order of per capita GDP, so that any trends in the data from richest to poorest countries can be seen. Before presenting the data all currencies were converted to U.S. dollars using the parallel exchange rates from the World Development Indicators, except for the 1985 price data, which was converted using parallel rates for 1985 from the World Currency Yearbook (Cowitt, 1987). It is hoped that the parallel exchange will give the best idea of the open market value of the currency. Of course, the income ordering will not necessarily be the same ordering as would be obtained using purchasing power parity exchange rates. But we wish to focus on market value exchange rates, and study the price differences between countries as a separate issue. Such price differences are an important and integral part of this model.

"INSERT Table 4 here" 
The first set of numbers in Table 4 is the per capita GDP of the various countries, as a percentage of the average value for these 10 countries. The model's per capita GDP is the sum of wage plus land rental income. The latter is rather negligible, so these reflect closely the wage values. When currencies are converted at market exchange rates, the income gap between countries is vast. For example, the two richest countries in our sample (Japan and the United States) have per capita incomes exceeding 100 times those of the two poorest countries (Bangladesh and Nigeria). The results above show that gaps like this can be produced by agglomeration models. In the model, international differences in income and wages exit because of different demands for labor in the different countries. The more manufacturing and tradeable service activity that is concentrated in a country, the richer it will be.

The next five statistics are price levels of different commodity groups, compared to the prices of the model's goods intended to represent them. In all cases, there is a decreasing trend in prices as we move from rich to poor countries. In the model, this decrease is caused by the decreasing cost of labor. Construction and non-tradeable services are modelled as identical industries in each country, and therefore the cost of output simply falls with the fall in the cost of labor. The other three industries form composite goods which include imports. Since imports incur shipping costs, it is somewhat surprising that these composites are cheaper in poor countries when a large fraction of production is performed in rich countries. Part of the reason the costs of the composites are lower in poor countries is that locally produced goods are cheap, and these locally produced goods figure relatively largely in the composite produced in those countries. The other reason is that the importation and final distribution of goods requires nontradeable services, which are cheaper in poor countries. 
Other papers document the strong negative correlation between generalized price levels and per capita income (Passé-Smith, 1993; Summers and Heston, 1991; and Bhagwati, 1984). The models in Fujita et al. (1999) produce the counter-factual result that the cost of living is higher in poor countries (p.253), but that is because in their model trade costs involve only shipping and they lack non-traded goods. Since the majority of goods are made in the rich country, the presence of only shipping costs will make those goods more expensive in the poor country. However, adding other importation costs, costs associated with final distribution, and non-traded goods and services could more than counteract this effect, as is done in our model.

The next six statistics are values of exports and imports of different commodity groups, as a percentage of GDP. There are no obvious trends in the data. Although the model has not matched the detail in the real world figures, it does have trade volumes that are quite realistic.

The next set of statistics shows the percentage of the workforce that is in industry, services, and agriculture. The industry figures from the model are the sum of the labor in the manufacturing and construction industries. In both the actual and artificial data, the percentage of the labor force in non-agricultural sectors declines as countries become poorer, although the trend is somewhat less pronounced in the model. The percentage in agriculture increases with increasing poverty. Poor countries employ relatively more labor in agriculture in part because there are few employment opportunities in other sectors; in part because expenditures on agriculture as a share of total expenditure is relatively high in poor countries; and in part because labor is cheap, and can be substituted for more expensive inputs - like manufactured goods. The program can obviously control the allocation of resources within a country in quite a straightforward way by changing the values of $N^{j}$ and $I^{j}$ for the different countries. The interesting thing 
is not that the model is able to produce reasonable values here, but that it can produce reasonable values for so many other things too, at the same time.

The next set of statistics show value added by activity as a percentage of each country's GDP. Since the model does a good job accounting for the allocation of labor between sectors, it also does well explaining value added in the various sectors.

\section{Conclusions}

The model in this paper reproduces a number of important observations about the international economy. First, it produces a range of values for per capita GDP quite similar to the real world values. Second, the observation that the prices of both tradeable and non-tradeable goods are generally lower in poor countries comes through. Third, the model can explain international differences in the allocation of labor between major sectors in the economy. At the same time, the model reproduces a wide range of other real world data at least roughly.

International agglomeration is, very fundamentally, a story about prices. The rich countries in this model are rich because the prices of the things they produce are high relative to the amounts of the inputs used, and the poor ones are poor because the prices of the goods they produce are low. These price differences are the result of the high demand for labor in rich countries caused by agglomeration of many production activities there. Of course, it is also possible that the stylized facts captured by this model could be captured by a quite different model, perhaps involving differences in total factor productivity or exogenous endowments of human or physical capital. What this model does demonstrate is that quite a realistic picture can be produced without such elements. 


\section{References}

Bhagwati, Jagdish N., "Why are Services Cheaper in the Poor Countries?" Economic Journal 94 (1984): 279-86.

Cowitt, Philip P. (ed.), World Currency Yearbook 1986-87, New York: International Currency Analysis Inc., 1987.

Fidrmuc, Jan and Jarko Fidrmuc, “Disintegration and Trade," Review of International Economics 11(5) (2003): 811-29.

Fujita, Masahisa, Paul Krugman, and Anthony J. Venables, The Spatial Economy; Cities, Regions, and International Trade, Cambridge, MA: MIT Press, 1999.

Head, Keith and Thierry Mayer, "Non-Europe: The Magnitude and Causes of Market

Fragmentation in the EU," Weltwirtschaftliches Archiv 136 (2000): 284-314.

Helliwell, John F., "National Borders, Trade and Migration," Pacific Economic Review 2(3) (1997): 165-85. , “Do National Borders Matter for Quebec's Trade?” Canadian Journal of Economics 29(3) (1996): 507-522.

Henderson, J. Vernon, Zmarak Shalizi and Anthony J. Venables, “Geography and Development," Journal of Economic Geography 1(1) (2001): 81-105.

Hummels, David, “Toward a Geography of Trade Costs,” Working Paper, Purdue University, 2001.

Krugman, Paul and Anthony J. Venables, "Globalization and the Inequality of Nations," Quarterly Journal of Economics 110(4) (1995): 857-80.

Krugman, Paul, “Increasing Returns and Economic Geography,” Journal of Political Economy 
99(3) (1991): 483-99.

Markusen, James R. and Anthony J. Venables, "Interacting Factor Endowments and Trade Costs: A Multi-Country, Multi-Good Approach to Trade Theory," Journal of International Economics 73 (2007): 333-54.

McCallum, John, "National Boarders Matter: Canada-U.S. Regional Trade Patterns," American Economic Review 85(3) (1995): 615-23.

Midelfart-Knarvik, Karen H., Henry G. Overman and Anthony J. Venables, "Comparative Advantage and Economic Geography: Estimating the Determinants of Industrial Location in the EU,” Working Paper, Centre for Economic Performance at LSE, 2001.

Passé-Smith, John T., "Could it be that the Whole World is Already Rich? A Comparison of RGDP/pc and GNP/pc Measures," in M.A. Seligson and J.T. Passé-Smith (ed.), Development and Underdevelopment - The Political Economy of Inequality, Boulder CO: Lynne Rienner Publishers, 1993.

Puga, Diego and Anthony J. Venables, "Agglomeration and Economic Development: Import Substitution vs. Trade Liberalisation,” Economic Journal 109(455) (1999): 292-311.

Redding, Stephen and Anthony J. Vennables, "Economic Geography and International Inequality"' Journal of International Economics 62(1) (2004): 53-82.

Summers, Robert and Alan Heston, "The Penn World Table (mark 5): An Expanded Set of International Comparisons, 1950-1988," Quarterly Journal of Economics 106 (1991): 327-368 United Nations, World Comparisons of Real Gross Domestic Product and Purchasing Power, 1985: Phase V of the International Comparisons Programme, New York: United Nations, 1994. 
Notes:

1. The usual references are Krugman (1991), Krugman and Venables (1995), Puga and Venables (1999), and Fujita, Krugman, and Venables (1999). For a review of the literature see Henderson, Shalizi, and Venables (2001).

2. Most papers in the NEG literature have focussed on the role of geographic location in explaining the clustering of economic activity (Fujita et al., 1999). The basic intuition is that firms located near their customers and suppliers to economize on transport costs. MidelfartKnarvik, Overman and Venables (2001) found that industrial structure also depends on endowments of skilled and scientific labor.

3. In the NEG literature there is great emphasis on increasing returns to scale at the firm level as the reason for clustering. However, internationally, things external to the firm such as corruption, unreliable services, political instability, and endowments of skilled labor will also play a role. Therefore, no attempt was made to include any possible effects from increasing returns to scale. 4. In the case of a poor country, there may not be much income left to allocate after subsistence levels have been satisfied. As a result, the subsistence levels will be important parameters in determining expenditure shares in poor countries. In comparison, the subsistence levels become less relevant for the residents of rich countries, and therefore the expenditure shares in rich countries may look quite different from those in poor countries. Note also that the more commonly used Cobb-Douglas utility function is a special case of the Stone-Geary, in which all subsistence parameters are set to zero. However, a well know feature of the Cobb-Douglas function is that the expenditure shares will be invariant to income.

5. The score value used to judge how well the model matches real world data seems to have local 
minima in which the program can become trapped as it moves through the 51-dimensional space defined by the parameters. The configuration presented is the best found, not necessarily the best that exists. Commented $\mathrm{C}++$ source code is available on request. 
Table 1. Share matrices

\begin{tabular}{lcccccc}
\hline India & Food & Manuf. & Construction & $\begin{array}{c}\text { Tradeable } \\
\text { Service }\end{array}$ & $\begin{array}{c}\text { Non-trade } \\
\text { Service }\end{array}$ & $\begin{array}{c}\text { Personal } \\
\text { Consumption }\end{array}$ \\
\hline Food & 0.00 & 0.03 & 0.02 & 0.00 & 0.02 & 0.40 \\
Manufact. & 0.10 & 0.43 & 0.35 & 0.21 & 0.21 & 0.14 \\
Construction & 0.02 & 0.05 & 0.00 & 0.11 & 0.08 & 0.07 \\
Trdble Srv. & 0.01 & 0.03 & 0.03 & 0.06 & 0.05 & 0.01 \\
N-trdble Srv. & 0.07 & 0.20 & 0.22 & 0.03 & 0.00 & 0.38 \\
Labor & 0.71 & 0.25 & 0.38 & 0.59 & 0.63 & 0.00 \\
Land & 0.08 & 0.00 & 0.00 & 0.00 & 0.00 & 0.00 \\
\hline USA & Food & Manuf. & Construction & Tradeable & Non-trade & Personal \\
& & & & Service & Service & Consumption \\
\hline Food & 0.00 & 0.01 & 0.00 & 0.00 & 0.02 & 0.06 \\
Manufact. & 0.22 & 0.43 & 0.30 & 0.14 & 0.14 & 0.13 \\
Construction & 0.02 & 0.02 & 0.00 & 0.03 & 0.10 & 0.06 \\
Trdble Srv. & 0.03 & 0.02 & 0.02 & 0.21 & 0.05 & 0.12 \\
N-trdble Srv. & 0.32 & 0.19 & 0.21 & 0.18 & 0.00 & 0.64 \\
Labor & 0.33 & 0.33 & 0.47 & 0.44 & 0.69 & 0.00 \\
Land & 0.08 & 0.00 & 0.00 & 0.00 & 0.00 & 0.00 \\
\hline
\end{tabular}

Notes: These shares are based on the authors' calculations. The source data for India is from Indiastat.com, and for the USA, from the Bureau of Economic Analysis. The basis for the analysis is the absorption matrix provided (1993-94 for India, 1998 for the USA). 
Table 2. Expenditure shares in agricultural production and personal consumption: the data and the model

\begin{tabular}{|c|c|c|c|c|c|c|c|c|c|c|c|c|}
\hline & \multicolumn{2}{|c|}{$\begin{array}{l}\text { Manufacturing } \\
\text { Share of Agric. }\end{array}$} & \multicolumn{2}{|c|}{$\begin{array}{l}\text { Construction } \\
\text { Share of Agric. }\end{array}$} & \multicolumn{2}{|c|}{$\begin{array}{l}\text { Tradeable Srv. } \\
\text { Share of Agric. }\end{array}$} & \multicolumn{2}{|c|}{$\begin{array}{l}\text { Non-trdble Srv. } \\
\text { Share of Agric. }\end{array}$} & \multicolumn{2}{|c|}{$\begin{array}{c}\text { Labor } \\
\text { Share of Agric. }\end{array}$} & \multicolumn{2}{|c|}{$\begin{array}{c}\text { Land } \\
\text { Share of Agric. }\end{array}$} \\
\hline & Data & Model & Data & Model & Data & Model & Data & Model & Data & Model & Data & Model \\
\hline$\overline{\text { Japan }}$ & $-\ldots$ & 0.211 & -- & 0.021 & -- & 0.027 & $\ldots$ & 0.292 & -- & 0.366 & -- & 0.081 \\
\hline USA & 0.220 & 0.211 & 0.020 & 0.021 & 0.030 & 0.027 & 0.320 & 0.288 & 0.330 & 0.372 & 0.080 & 0.081 \\
\hline Brazil & -- & 0.204 & -- & 0.021 & --- & 0.026 & -- & 0.256 & --- & 0.412 & --- & 0.081 \\
\hline Russia & -- & 0.176 & -- & 0.020 & -- & 0.021 & -- & 0.187 & --- & 0.515 & -- & 0.081 \\
\hline China & -- & 0.000 & -- & 0.017 & -- & 0.000 & -- & 0.000 & --- & 0.902 & -- & 0.081 \\
\hline Indonesia & -- & 0.032 & -- & 0.017 & -- & 0.000 & -- & 0.000 & --- & 0.869 & -- & 0.081 \\
\hline India & 0.100 & 0.107 & 0.020 & 0.019 & 0.010 & 0.010 & 0.070 & 0.067 & 0.710 & 0.716 & 0.080 & 0.081 \\
\hline Pakistan & - & 0.107 & -- & 0.019 & -- & 0.009 & -- & 0.065 & -- & 0.720 & - & 0.081 \\
\hline Bangladesh & -- & 0.000 & -- & 0.017 & -- & 0.000 & -- & 0.000 & --- & 0.902 & -- & 0.081 \\
\hline \multirow[t]{3}{*}{ Nigeria } & $-\ldots$ & 0.015 & $-\ldots$ & 0.017 & $\ldots$ & 0.000 & $-\ldots$ & 0.000 & $-\ldots$ & 0.887 & $-\ldots$ & 0.081 \\
\hline & \multicolumn{2}{|c|}{$\begin{array}{l}\text { Agric. Share of } \\
\text { Consumption }\end{array}$} & \multicolumn{2}{|c|}{$\begin{array}{l}\text { Manu. Share of } \\
\text { Consumption }\end{array}$} & \multicolumn{2}{|c|}{$\begin{array}{l}\text { Cnstrctn Share of } \\
\text { Consumption }\end{array}$} & \multicolumn{2}{|c|}{$\begin{array}{l}\text { Trdble Srv. Share } \\
\text { of Consumption }\end{array}$} & \multicolumn{2}{|c|}{$\begin{array}{l}\text { Non-trdble Srv. } \\
\text { Share of Consump }\end{array}$} & & \\
\hline & Data & Model & Data & Model & Data & Model & Data & Model & Data & Model & & \\
\hline Japan & -- & 0.170 & $-\ldots$ & 0.137 & --- & 0.056 & -- & 0.110 & $-\ldots$ & 0.527 & & \\
\hline USA & 0.060 & 0.165 & 0.130 & 0.136 & 0.060 & 0.058 & 0.120 & 0.105 & 0.640 & 0.536 & & \\
\hline Brazil & -- & 0.219 & -- & 0.104 & -- & 0.064 & -- & 0.082 & -- & 0.531 & & \\
\hline Russia & -- & 0.289 & -- & 0.098 & -- & 0.073 & -- & 0.046 & --- & 0.494 & & \\
\hline China & --- & 0.428 & -- & 0.241 & --- & 0.077 & -- & 0.001 & --- & 0.253 & & \\
\hline Indonesia & --- & 0.416 & -- & 0.173 & --- & 0.076 & -- & 0.004 & --- & 0.331 & & \\
\hline India & 0.400 & 0.382 & 0.140 & 0.130 & 0.070 & 0.076 & 0.010 & 0.010 & 0.380 & 0.402 & & \\
\hline Pakistan & -- & 0.379 & --- & 0.128 & --- & 0.076 & --- & 0.017 & --- & 0.401 & & \\
\hline Bangladesh & --- & 0.434 & -- & 0.215 & -- & 0.076 & -- & 0.000 & --- & 0.274 & & \\
\hline Nigeria & $\ldots$ & 0.397 & $\ldots$ & 0.194 & $\ldots$ & 0.078 & $\ldots$ & 0.007 & $\ldots$ & 0.324 & & \\
\hline
\end{tabular}

Notes: Countries are arranged in descending order of per capita GDP, so that any trends in the data from richest to poorest countries can be seen. 
Table 3. Trade costs: the data and the model

\begin{tabular}{lcccccc}
\hline & \multicolumn{2}{c}{$\begin{array}{c}\text { International Transport } \\
\text { \% of Manuf. Imports }\end{array}$} & \multicolumn{2}{c}{$\begin{array}{c}\text { Final Distribution } \\
\text { \% of GDP }\end{array}$} & \multicolumn{2}{c}{$\begin{array}{c}\text { Model Importing Cost } \\
\text { \% of Import Value }\end{array}$} \\
& Data & Model & Data & Model & Food & Manufact. \\
\hline Japan & --- & 11.8 & --- & 5.9 & 92.9 & 41.5 \\
USA & 10.3 & 13.4 & 6.9 & 6.1 & 91.3 & 38.7 \\
Brazil & 17.7 & 15.8 & --- & 6.9 & 84.5 & 32.5 \\
Russia & -- & 20.5 & -- & 8.2 & 71.2 & 21.4 \\
China & -- & 24.3 & -- & 10.4 & 39.7 & 6.8 \\
Indonesia & -- & 24.0 & -- & 9.8 & 51.3 & 11.0 \\
India & -- & 24.1 & 12.0 & 9.2 & 54.2 & 11.9 \\
Pakistan & -- & 23.0 & -- & 9.2 & 58.7 & 14.1 \\
Bangladesh & -- & 24.4 & -- & 10.1 & 47.9 & 9.8 \\
Nigeria & -- & 24.1 & -- & 9.9 & 50.6 & 10.8 \\
\hline
\end{tabular}

Notes: Data on international transport is from Hummels (2001). Data on final distribution is calculated from figures on wholesale and retail trade in absorption matrices used in Table 1. 
Table 4. International comparisons: the data and the model

\begin{tabular}{|c|c|c|c|c|c|c|c|c|c|c|c|c|}
\hline \multirow[t]{2}{*}{$\begin{array}{l}\text { Income } \\
\text { Rank }^{\text {a }}\end{array}$} & \multicolumn{2}{|c|}{$\begin{array}{c}\text { Per Capita } \\
\text { GDP }^{\mathrm{b}}\end{array}$} & \multicolumn{2}{|c|}{$\begin{array}{c}\text { Construction } \\
\text { Price }^{\mathrm{b}}\end{array}$} & \multicolumn{2}{|c|}{$\begin{array}{l}\text { Non-tradeable } \\
\text { Srvc. Price }{ }^{b}\end{array}$} & \multicolumn{2}{|c|}{$\begin{array}{l}\text { Food } \\
\text { Price }^{b}\end{array}$} & \multicolumn{2}{|c|}{$\begin{array}{c}\text { Manufact. } \\
\text { Price }^{\mathrm{b}}\end{array}$} & \multicolumn{2}{|c|}{$\begin{array}{c}\text { Tradeable } \\
\text { Srvc. Price }\end{array}$} \\
\hline & Data & $\underline{M}$ & Dala & Model & Data & Model & Data & Model & Data & odel & Data & Model \\
\hline 1 & 451.1 & & 200.7 & & 202.9 & & 217.1 & & 183.6 & & 223.1 & 4.8 \\
\hline 2 & 8.9 & & .9 & & 276.3 & & 174.8 & & 178.7 & & 188.8 & \\
\hline 3 & 7.1 & 2 & - - & & - - & & - - & & - - - & & - - - & 1.4 \\
\hline 4 & & & & & & & & & 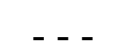 & & & 4.4 \\
\hline 5 & & & - & & $\cdots$ & & $-\cdots$ & & - . - & & - . - & J \\
\hline 6 & & & & & -1 & & - . - & & - . - & & $\ldots$ & 2.2 \\
\hline 7 & & & & & 46. & & 73.4 & & 107.7 & & 80.7 & 47.2 \\
\hline 8 & & 12 & & & 33. & & 53.2 & & 67.6 & & 62.9 & 9.1 \\
\hline 9 & & & .6 & & 9 & & 3.8 & & 23.0 & & 9 & .3 \\
\hline 10 & 1.3 & 9.5 & 54.8 & 28.1 & 31.4 & 19.1 & 62.6 & 21.8 & 39.3 & 88.5 & 35.0 & 53.0 \\
\hline Rank & & & & & & & & $\mathrm{ts}^{\mathrm{c}}$ & & orts & & \\
\hline
\end{tabular}

Data Model Data Model Data Model Data Model Data Model Data Model

\begin{tabular}{|c|c|c|c|c|c|c|c|c|c|c|c|c|}
\hline 1 & 0.2 & 0.2 & 9.4 & 4.0 & 1.6 & 2.5 & 1.3 & 0.5 & 5.2 & 4.3 & 2.9 & 1.8 \\
\hline 2 & 0.8 & 0.1 & 7.0 & 2.4 & 2.9 & 3.2 & 0. & 0.4 & 10.0 & 5 & .0 & 0.9 \\
\hline 3 & 2.2 & 0.9 & 4.3 & 13.9 & 0.9 & 10 & 0 & 1.1 & 6.5 & .4 & 0 & 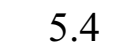 \\
\hline 4 & 1.4 & 3.1 & 22.2 & 19.8 & 4.7 & .9 & 3.8 & 1.8 & 10.3 & 19.8 & 8 & 2 \\
\hline 5 & 1.5 & 1.2 & 17.6 & 11.2 & 2.5 & 0 & 0 & 1.7 & 13.0 & & 0 & .1 \\
\hline 6 & 8.6 & 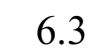 & 36.4 & 21.4 & 4.6 & 4.3 & 6. & 2.7 & 27.8 & 3.8 & 2.3 & .5 \\
\hline 7 & 1. & & 6.2 & 1 & 2 & 4 & $1 .($ & .5 & 9.0 & 9.4 & 3 & $t .0$ \\
\hline 8 & 2.2 & 7.1 & 11 & 2 & 2.2 & 2.4 & 4. & 2.8 & 11.3 & .2 & 3.4 & .3 \\
\hline 9 & 1.1 & 12 & 11.0 & 25.4 & 0.6 & 6 & 3.2 & 2.6 & 12.5 & 29.7 & 8 & .9 \\
\hline 10 & . & 11.1 & $\ldots$ & 24.5 & 2.1 & 2.3 & $\ldots$ & 2.1 & $\ldots$ & 29.5 & 9.8 & 6.2 \\
\hline $\begin{array}{l}\text { Income } \\
\text { Rank }^{a}\end{array}$ & \multicolumn{2}{|c|}{$\begin{array}{l}\text { Agricultural } \\
\text { Labor }^{\mathrm{d}}\end{array}$} & \multicolumn{2}{|c|}{$\begin{array}{c}\text { Industrial } \\
\text { Labor }^{d}\end{array}$} & \multicolumn{2}{|c|}{$\begin{array}{l}\text { Services } \\
\text { Labor }^{d}\end{array}$} & \multicolumn{2}{|c|}{$\begin{array}{l}\text { Agric. Value } \\
\text { Added }^{c}\end{array}$} & \multicolumn{2}{|c|}{$\begin{array}{l}\text { Indstrl Value } \\
\text { Added }^{c}\end{array}$} & \multicolumn{2}{|c|}{$\begin{array}{l}\text { Srvcs Value } \\
\text { Added }^{\mathrm{c}}\end{array}$} \\
\hline & Data & Iodel & Data & Model & Data & Model & Data & Model & Data & Model & Data & Model \\
\hline 1 & 5.5 & 2.7 & 31.6 & 25.8 & 2.9 & 71.5 & 1.9 & 3.3 & 41.3 & 25.6 & 6.8 & 71.0 \\
\hline 2 & 2.6 & 3.3 & 4 & 25.4 & 0 & 71.3 & 1.6 & 4.0 & 25.0 & 25.2 & 3.4 & 0.8 \\
\hline 3 & 25.4 & 5.1 & 17.9 & 25.6 & 56.7 & 69.3 & 7.2 & 6.0 & 24.8 & 25.4 & 8.0 & 8.6 \\
\hline 4 & - - - & 10 & - - & 22.8 & - - - & 6 & 6.7 & .9 & 32.3 & 22.4 & 0.9 & 5.7 \\
\hline 5 & - - & 3 & - - - & 27.4 & - - - & 42.0 & .4 & 5 & 48.7 & 26.7 & 2.9 & 0.9 \\
\hline 6 & .4 & & 8.5 & 8 & 40.1 & 48.8 & .5 & 3 & 45.3 & 21.2 & 5.2 & 47.5 \\
\hline 7 & -- & 1 & $\cdots$ & 2 & -- & & .7 & 21.3 & 22.6 & 25.1 & 0.7 & 3.5 \\
\hline 8 & 5 & 2 & 15.2 & 2 & 29.2 & 56 & .5 & 6 & 22.9 & 21.6 & 2.6 & 4.8 \\
\hline 9 & 66.0 & 3 & 9.2 & 20.7 & 24.9 & 43 & 22.2 & 37.8 & 27.9 & 20.0 & 49.9 & 42.1 \\
\hline 10 & $\ldots$ & 31.9 & $\ldots$ & 20.4 & $\ldots$ & 47.8 & 31.3 & 33.8 & 40.6 & 19.8 & 28.1 & 46. \\
\hline
\end{tabular}

Notes: ${ }^{a}$ Per capita income rank: 1. Japan, 2. USA, 3. Brazil, 4. Russia, 5. China, 6. Indonesia, 7. India, 8. Pakistan, 9. Bangladesh, 10. Nigeria. ${ }^{\mathrm{b}}$ Percentage of average value of the observations. ${ }^{\mathrm{c}}$ Percent of GDP. ${ }^{\mathrm{d}}$ Percent of total labor. 